European journal of American studies

$10-2$ | 2015

Summer 2015, including Special Issue: (Re)visioning

America in the Graphic Novel

\title{
Ti-Girl Power: American Utopianism in the Queer Superhero Text
}

\section{Matt Yockey}

\section{(2) OpenEdition}

\section{Journals}

Electronic version

URL: https://journals.openedition.org/ejas/11014

DOI: 10.4000/ejas. 11014

ISSN: 1991-9336

Publisher

European Association for American Studies

Electronic reference

Matt Yockey, "Ti-Girl Power: American Utopianism in the Queer Superhero Text", European journal of American studies [Online], 10-2 | 2015, document 9, Online since 14 August 2015, connection on 08 July 2021. URL: http://journals.openedition.org/ejas/11014 ; DOI: https://doi.org/10.4000/ejas.11014

This text was automatically generated on 8 July 2021.

Creative Commons License 


\title{
Ti-Girl Power: American Utopianism in the Queer Superhero Text
}

\author{
Matt Yockey
}

\section{Introduction}

1 In the graphic novel God and Science: Return of the Ti-Girls (2012), about a multiethnic group of female superheroes, writer-artist Jaime Hernandez offers a compelling example of the creator who uses his own subjectivity as a mode of textual production. By marrying his childhood love of Silver Age superhero comic books to the autobiographical qualities of alternative comic books, Hernandez actualizes his dual hyphenated subjectivities of pro-fan and Mexican-American. In the process, he collapses a number of other binaries: the past and the present, the mundane and the fantastic, and the private and the public. In turning to the superhero genre, historically so heavily invested in idealizing a white, heteronormative American identity (that proverbial "truth, justice, and the American way"), Hernandez successfully subverts the homogenizing strategies of national rhetoric and of mass culture. In doing so, he gives voice to and makes visible the otherwise unheard and previously unseen in mainstream superhero comic books, uncovering the latent subversive appeal of the genre. God and Science undermines an Anglo-American master narrative sustained by the Silver Age superhero comics Hernandez is so clearly inspired by. This is both a diegetic and extra-diegetic master narrative, thus linking creator with fantasy, and citizen with nation. As a result, Hernandez radically redirects the utopian impulse that resides at the heart of the genre. The transformation of the everyday into the fantastic of conventional superhero comic books is here revised as the assertion of the fantastic embedded in the everyday. This fantastic is the expression of individual nonheteronormative utopian desire. In foregrounding the personal, Hernandez employs a collective outlook on two registers: as a Chicano and as a comic book fan. His very personal take on the superhero genre embraces marginalization in a utopian gesture constituted first and foremost by affect. It is through the affective register of nostalgia (the recollection of assimilation within and resistance to hegemony via the superhero) 
that Hernandez rearticulates the excessive bodies of superheroes to reveal the inherent non-heteronormativity, or queerness, of the genre and of fandom.

2 Hernandez follows the strategy of queer Chicano writer Manuel Muñoz, who "decenters queer speaking subjects," enabling "a deeper understanding of the intersubjective and social contexts in which queer subjects come into being" (Martiñez 227). By using superheroes as vehicles for this decenteredness, Hernandez intersects his identities as a Chicano and as a comic book fan. He articulates the "queerness" of each in respect to Anglo hegemony as a means of inserting himself into the discourse of both national and popular culture (the two condensed within the figure of the superhero). Further, in using the term queer for a graphic novel by a straight writerartist and which does not feature any explicitly gay characters, I turn to Alexander Doty's formulation of the queer in popular culture. Doty questions "the cultural demarcations between the queer and the straight... by pointing out the queerness of and in straights and straight cultures, as well as that of individuals and groups who have been told they inhabit the boundaries between the binaries of gender and sexuality" (xv-xvii). Thus, Hernandez's non-white, female superheroes are Doty's "binary outlaws," figures who challenge the rigid gender categories of conventional superhero comic books (xvi). Further, as the male author of a narrative comprised almost totally of women (sightings of male characters in God and Science are rare and brief), and as the producer who flags his subjectivity as a consumer, Hernandez himself is a binary outlaw, confirming Doty's use of the term queer "to suggest a range of nonstraight expression in, or in response to, mass culture" (xvi). According to Doty, “'Uncloseted' or brought forward by equal attention to producers and readers... the queerness in and of mass culture might be used to challenge the politics of denotation and connotation as it is traditionally deployed in discussing texts and representation. In this way the closet of connotation could be dismantled, rejected for the oppressive practice it is" (xii). Hernandez actualizes Doty's proposed strategy in large part by collapsing the divide between producer and consumer. In doing so, he draws out the connotative queerness of the superhero and, by extension, his own inherent queerness and that of his readers.

\section{Queer as Super-Folk}

3 Superheroes are queer in a connotative way; they are excessive figures who, by definition, exist at the margins of society, even as they defend that society. This queerness of the superhero genre has always lingered in the shadows cast by the visually excessive depictions of men in colorful, skintight costumes constantly grappling with one another. In his book Seduction of the Innocent (1954), Fredric Wertham famously condemned characters such as Batman and Robin for promoting a homosexual lifestyle. To this day a vocal contingent of superhero fans vociferously rejects Wertham's interpretation in a strategy that Andy Medhurst calls "reheterosexualization" (159). Hernandez, in fact, resists both Wertham's negative-gay reading and the re-heterosexualization by fans of characters like Batman. He responds to what Doty terms "cultural heterocentrism and homophobia" endemic to straight readings of mass culture (xiii). By revising the white male homosociality of the genre as multicultural female homosociality, Hernandez exposes the incipient positive queerness of the genre, its inherent concerns with the plasticity of private and public 
identities. In doing so, Hernandez more fully actualizes the utopian potential of America as a multicultural nation than mainstream superhero comic books do, with their more homogenized reflection of national hegemony.

4 Scott Bukatman contends that "superhero comics embody social anxiety," particularly regarding "the adolescent body and its status within adult culture" (49). Hernandez exploits this universal appeal of the superhero as a signifier of social difference in order to inject the particularities of his own social "difference" in a genre that otherwise typically displaces actual social difference into the realm of the fantastic (e.g., blue-skinned aliens as victims of prejudice). In the intersection of his own identity with the female superheroes of God and Science, Hernandez expands the scope of the genre's anxieties about identity, actualizing the most positive qualities of the superhero and the superhero fan as marginalized subjects. They become liminal figures who are what Marjorie Garber calls "unmarked transvestites," representatives of a “'category crisis'... a failure of definitional distinction, a borderline that becomes permeable, that permits of border crossings from one (apparently distinct) category to another" $(356,16)$. In God and Science the "crisis" that multi-ethnic, female superhero homosociality provokes is that of the integrity of patriarchy, heterocentrism, and whiteness as normative social constructs. As Teresa de Lauretis argues, queerness as a social position is "both interactive yet resistant, both participatory yet distinct" (iii). In assimilating his subjectivity with tropes of mainstream superhero comics, Hernandez resists the marginalization of non-whites and women in the genre, articulating queerness as, according to Doty, "an attitude, a way of responding, that begins in a place not concerned with, or limited by, notions of a binary opposition of male and female or... homo versus hetero" (xv). Hernandez's work is thus queer in its deconstruction of the producer/consumer binary as a primary strategy by which he critiques the standard gender and racial politics of the genre.

5 The narrative of God and Science centers around the non-super powered Maggie Chascarillo, the bi-sexual, Mexican-American protagonist of Hernandez's long-running "Locas" continuity (about life in a California barrio) in his (and brother Gilbert's) Love and Rockets comics. ${ }^{i}$ Though Maggie is only a supporting player in God and Science, Hernandez situates her as a pivotal figure at the border between the mundane world of the apartment complex she manages and the fantastic realm occupied by female superheroes and supervillains. Importantly, many of the superheroes that appear in God and Science exist as characters in Maggie's collection of old comic books (which she refers to throughout in order to anticipate events and to help the superheroes) and some of them are also tenants in her building. In this way, Hernandez highlights to his readers his own reliance on Silver Age superhero comic books as guideposts in creating God and Science. Maggie's interest in superheroes also translates to her friend and tenant Angel, who, in the process of the story, gains super powers and becomes the superhero Boot Angel. With Maggie serving as a stand-in for both the reader and Hernandez (he has frequently noted that she is the character that is most like him), the rest of the narrative unfurls in a crazy-quilt series of searches, battles, outer space adventures, origin stories, and emotional climaxes. The Ti-Girls come out of retirement to hunt down Penny Century,ii who, pregnant with her fourth child, has made a deal with the female sorcerer Vakka Boome: in return for super powers (termed "the gift"), Penny promises Vakka her unborn child. After getting her powers, Penny reneges on her promise and dips her toddler daughter Maite in the same bath. Mother and 
daughter flee "on a mission, not to aid the cause of justice, but to have fun and cause mischief wherever they pleased" (Hernandez 17). Due to the effects of Vakka's bath, Maite begins to age rapidly and after becoming a teenager in a matter of months bitterly parts ways with her mother. Meanwhile, Penny gives birth to a one-inch tall daughter (another result of the magical bath water), whom she names Thimbelina. During a battle she loses her newborn daughter and a grief-stricken Penny tears through the universe searching for her lost children, leaving a path of destruction in her wake.

6 Much of the rest of the plot revolves around the search for Penny and her children by the Ti-Girls (Espectra, the Weeper, and Golden Girl), Alarma (a member of rival allfemale superhero squad the Fenomenons), and Boot Angel. Meanwhile, Vakka Boome, intent on getting Thimbelina for herself, teams with a bitter Maite, the Russian cowgirl supervillain Kalamity Jane Burkeskova, and Espectra Negra. This last villain is Espectra's evil twin, created years earlier when the Ti-Girl leader Fuerza, chasing "the mad Dr. Blitz" into his time portal, was split into two embodied subjectivities. The good Fuerza became Espectra and her evil twin, Espectra Negra, went into the future. In the end, Vakka Boome and her cohorts are vanquished and Penny, Maite, and Thimbelina are happily reunited. In the process, it is revealed that Penny and Maggie are "not regular flesh and blood" and thus do not belong in this narrative universe; when the superheroes try to read Maggie's comic books, all they see are blank pages. Using her Ray of Truth, the Weeper sends Penny, Maite, Thimbelina, and Maggie away. In the epilogue we find that Penny (resuming her non-superhero status) and Maggie have had their memories of the previous events removed and are no longer aware of the presence of superheroes around them. In an ambiguous conclusion, Angel's kid sister Modesta retains the secret knowledge that her sister and mother were once superheroes, indicating that "the gift" may carry on with her.

7 As all of this suggests, Hernandez clearly aims for absurdist superhero fun that still bears emotional and cultural weight. In part, God and science evokes playfully imaginative Silver Age superhero comic books that engage with the border between the fantastic and the mundane, such as Jimmy Olsen stories in which "Superman's pal" variously becomes a "giant turtle man," elastic, a werewolf, and a "human octopus." Jimmy's acquisition of superpowers equates him with the adult authority of Superman but, in their cartoonishly fantastic nature, anchor him in childhood. Just as those Jimmy Olsen stories destabilize the boundary between childhood and adulthood, God and Science rejects what Bukatman characterizes as contemporary comics' "problematic and painfully reductive definitions of masculine power and presence" (51).iii Hernandez's themes are serious while avoiding the adolescent angst and dark violence that characterizes so many contemporary superhero comic books marketed to an adult audience. In fact, Hernandez, who long maintained his distance from the genre, stated in an email to this author that he created God and Science in part because he did not like the way in which modern superhero comic books are handled. By engaging with the genre partially as a fan, then, Hernandez comments on how comic book readers actively participate in the constitution of their own identities through representations of superheroic physical and emotional excess that foreground "feminine" emotional tropes (in particular love) over "masculine" ones (especially anger). This reflexivity is key to Hernandez's implication of his own subjectivity in the diegesis. In this regard, God and Science must be understood in relation to Hernandez's biography: born in 1959 in southern California to a Mexican father and Mexican-American mother, his 
childhood was steeped in popular culture, especially comic books, monster movies, and Mexican wrestling. Growing up, Hernandez and his brothers drew their own comic books, as many children do, but for Hernandez and brother Gilbert these homemade efforts were the start of their evolution into comic book professionals. Reflecting on his childhood, Hernandez says,

We grew up with comics... I wanted to draw comics my whole life... It was the perfect means for expressing myself in stories, and it was inexpensive... I liked drawing rocket ships, superheroes, and things like that when I was younger, and that's why you see a lot of them in the early comics. But it also came out of the life I was living growing up in the barrio in Oxnard, California... Whether [readers] understand it or not, [my] comics aim to communicate a vision of the Chicano community so readers can see what it's all really about. (Aldama 120-124)

Subsequently, Hernandez's belated take on the superhero genre openly acknowledges the role that the genre has played as part of his identity as a Chicano growing up in 1960s and 1970s America. In doing so, he penetrates the barrier between Chicano and non-Chicano without compromising the integrity of his ethnic identity; that is, without yielding to the homogenizing power of mass culture. Rather, he molds it for his own purposes. This maneuver in turn actualizes America's utopian promise of a pluralistic society. That Hernandez turns to mass culture to affirm this political position speaks to what Arlene Dávila sees as a vital strategy by which Latinos may assert their identities in modern America. Writing about the relationship between mass media and the public sphere, Dávilacontends that Latinos

are challenged to redefine what we mean by public and political projects, as well as the relationship between citizenship and consumption, as a step toward exposing inequalities and injustice in the realms of consumption, such as in people's access to the media and to other mechanisms of cultural interpellation and identity formation. (Dávila 10)

In turning to alternative comic books, an inexpensive medium that affords him the opportunity for self-expression, Hernandez meets the challenges laid out by Dávila.

10 In the process of embedding his own subjectivity in his work, Hernandez compels all of his readers to consider their own desires and identity in respect to superhero comic books. By extension, he presents an opportunity for readers to rethink the boundaries of national identity. This is made most clearly evident by Maggie's role as comic book reader and witness to the superhero shenanigans of the plot. The graphic novel opens with Maggie confiding to Angel that she believes another tenant, Alarma Kraktovilova, is secretly a member of the Fenomenons. Her suspicions are confirmed by the storylines in her collection of comic books, which portray the exploits of three different female super-teams: the Fenomenons, the Zolars, and the Ti-Girls. Regarding this last group, Maggie confesses, "Them I've never been able to find much on. They were from the Sixties and Seventies and they were made up solely of rejects from other super teams" (Hernandez 7). Even within the marginalized world of female superheroes, the Ti-Girls exist at its outermost edge, marking them as especially attractive representatives of outsider subjectivity. Consumerism informs desire for and knowledge of the superhero (which, when articulated by Hernandez as the subject of personal meaning-making, is knowledge of self) but the machinations of the marketplace also set limits on that knowledge. Those limits can only be exceeded by the intersection of twin desires: Maggie's efforts to learn if superheroes actually exist and Angel's own dream of becoming a superhero. 
11 These desires begin to be satisfied the following day when Maggie and Angel attend a comic book show and buy back issues of Ti-Girls comic books. Angel, who describes the Ti-Girls as "the reject loser team," is motivated to press beyond these limits of the commodified mass culture text and, subsequently, her own perceived limitations. Almost immediately, then, Hernandez resets the limits of the conventional superhero comic book. Importantly, he achieves this by way of the codes of alternative comic books derived from underground comix of the late 1960s and early 1970s. Following the model of underground comix, alternative comics such as God and Science transform the medium into what Charles Hatfield describes as "a vehicle for the most personal and unguarded of revelations" and they "ironize the comic book medium itself" (Hatfield 7-8). In God and Science alternative comic book tropes intersect with the superhero genre to produce a new iteration of the superhero that reflects Hernandez's subjectivity. Importantly, in foregrounding the purchase of comic books at a comic show and later a comic shop (where Maggie seeks out more issues of Ti-Girls comics), their consumption at home, and their direct application to life, Hernandez marks fandom itself as a utopian enterprise. This is underscored by the fact that Maggie's purchase of The Adventures of Santa Claus leads her to the (apparently) actual Santa at a department store, who gives her an issue of Penny Century, which depicts her friend as a superhero. Through the figure of Santa Claus, the collapse of the boundary between the fantastic and the everyday is managed by the affect of childhood, i.e., the utopian possibilities only available via the subjectivity of a child. Hence, when Espectra Negra cries in anguish that there is no Santa in the future, Hernandez is clearly marking the transition into adulthood as one that stifles utopian thought. That Espectra and Espectra Negra were produced by a split in the subjectivity of the superhero Fuerza indicates that, according to Hernandez, the bifurcation of the superhero must be understood in terms of the binary between (utopian) childhood and (dystopian) adulthood. By the end of God and Science, the two Espectras are reintegrated and Fuerza returns, confirming that the reconciliation of this dialectic produces the ideal subjectivity, the marriage of adult agency with the powers of childhood imagination. This subjectivity is ideal because in synthesizing the imaginative vision of childhood with the agency (and social responsibility) of adulthood, cultural pluralism is affirmed and actualized. Thus, the reconstitution of Fuerza embodies and is a fantastic representation of a comparable integration by Hernandez himself, confirmed by the creation of God and Science.

\section{More Than a Feeling}

12 The comic book that Santa gives Maggie not only provides her with important answers to the events unfolding around her but it is material evidence of the remediation of personal desire by a mass culture commodity (emphasized by the cover blurb "Comics For You!"). This is reflexively reinforced by the very existence of God and Science; the graphic novel offers material evidence of a fan-turned-pro's utopian rearticulation of the superhero. Production and consumption of superhero comic books become coequal and cyclical activities that are utopian in their destabilization of a causal relationship (production necessitates consumption and vice versa) and the articulation of individual subjectivity. The processes of consumption and production validate the utopian gesture; they are fueled by the desire for utopia and are sustained 
by the impossible satisfaction of that desire. Just as superheroes perpetually struggle toward utopian closure in their narratives, so too does the utopian form of the serial comic book remain ongoing. In both content and form, the superhero comic book is defined by affective subjectivities-of the constant desires of superheroes, of readers, and of creators.

13 Angel's desire is played out early in the story when she climbs onto the roof of the apartment building in a homemade superhero costume, exposing the queer desire for the hidden, better self. Importantly, this revelation of personal utopian desire is tacitly legitimated by Alarma, who appears on the rooftop in her superhero guise (an important signifier of difference, since her superhero name is also her first name). Only when Angel, the comic book reader, actualizes her desire to be a superhero does the secret world of the superhero manifest itself. Importantly, the expression of Angel's desire is also key to her actually acquiring powers, which occurs shortly after this episode on the roof. Whereas in conventional superhero comic books, the (usually male) superhero often gains powers through a traumatic accident and then acquires a costume, here super powers only manifest themselves after the subject has expressed a desire for them and willfully reinscripted her body by donning a costume (that is, willfully reconfigured her social meaning). In this pivotal encounter, Hernandez first offers his interrogation of the mainstream superhero comic book. Calling herself Boot Angel, Angel asks Alarma "Do [the Fenoms] have room for a fat ethnic chick who wants to do her part in ridding the world of bigotry and bulimia?" (Hernandez 9). Body type and ethnicity set the limits of the mainstream superhero genre and Angel expands its menu of possibilities in her desire to be a superhero. This reflects Hernandez's own wish to defy the ethnic and gender boundaries of the genre. By demonstrating through the rest of God and Science that the genre readily can accommodate such an expansion of its ideological borders, Hernandez exposes the latent queerness of the genre as an empowering gesture for the superhero-wannabe, for Hernandez himself, and for his readers.

14 God and Science is centrally about utopian desires: Maggie's for superheroes to be real, Angel's to become a superhero, and Hernandez's to remediate and reconfigure the boundaries of Silver Age superhero comics. In this way the graphic novel follows Fredric Jameson's argument that representations of utopia are not "the exhibit of an achieved Utopian construct, but rather the story of its production and of the very process of construction as such" (217). Angel's is the classic origin story, the tale of becoming that is constantly reenacted in the genre, hence the ritualistic shifting from secret to superhero identity that defines the superhero. As an expression of utopian desire, the superhero confirms Jameson's contention that utopian politics is about "the dialectic of Identity and Difference, to the degree to which such a politics aims at imagining, and sometimes even at realizing, a system radically different from this one" (xii). Importantly, this aligns the superhero with the goals of American identity, based on the dialectic between individualism and the collective. The inherent pluralism of American identity is the source for its most profound identity crisis. The nation's multiculturalism signifies its democratic utopian appeal, even as that pluralism is typically regarded as threatening by the white status quo. America is thus inherently utopian in Jameson's terms of identity and difference. What defines America becomes a matter of perspective in terms of the difference one pines for (most often in competing terms of regressive nostalgia and progressive visions of difference). Such a radical 
reimagining of a different system depends upon representing the utopian production of subjectivity. The true story of the superhero in God and Science is the rearticulation of a new, potentially utopian self, both by Angel and by Hernandez himself, each presented as a subject taking control of their socially inscribed identity, reveling in liminality and hybridity. Hernandez subverts the conservative impulse of nostalgia by turning to his childhood relationship with both American and Mexican popular culture to imagine a radically different future for the nation.

15 Key to this is Hernandez's privileging of female agency and non-white perspectives that he locates originally in his own history with mainstream comic books. It is revealed, for example, that Espectra was an illegal immigrant when she began her superhero career as Fuerza and that she was once a wrestler. As she puts it, "All super heroes from Mexico started out in the ring," actualizing the intersection of American and Mexican popular culture for Hernandez (Hernandez 22). His work thus corresponds to and expands upon what José David Saldívar terms the corrido, a reflexive social text which is both historical and personal, which comes from a collective outlook and experience, and which resists Anglo-American hegemony (172). Hernandez recalls that one of his favorite comic books as a child was a 1961 Superman comic book: "Superman dies. Supergirl then comes in and kicks everyone's asses. And there's no question about her being a woman taking over or anything" (Hignite 51). iv Of further significance is that Hernandez credits his mother with supporting his love of comics and serving as a model for his pursuit of a career in comics. As a former comic book reader herself, she encouraged her children to read them and shared with them her own portraits of her favorite Golden Age superheroes. Thus Hernandez's "birth" as a fan and then professional originates in the mass culture stewardship offered by his mother, the intersection between the private and the public. It is also not incidental that, following the death of his father when Hernandez was eight, Hernandez and his five siblings were raised by his mother and their aunts, echoing the message of post-patriarchal female empowerment he found so attractive in the Supergirl story. Consequently, the female superheroes of God and Science are defined by self-transformation beyond the control of patriarchy. The Ti-Girls were first brought together by Dr. Zolar, the story's central patriarchal figure, whose significance is reduced by the fact that he is in a coma throughout the story and otherwise only appears as a background figure in flashbacks. Further, Dr. Zolar had no hand in the creation of any female superheroes, just their organization into teams (underlining the thematic paradox of American identity). In fact, all women are born with "the gift." As Angel's mother explains to her, "It's... beautiful, the mystery of it. See, all women are born with it, but most lose it at a really early age. It's too subtle to notice because most blossom when much older.... Guys don't get it. They gotta go out an' have lab accidents and other stuff to get their cojones but we got it born right in us" (Hernandez 82). Hernandez willfully subverts the patriarchal power of reproduction so typical of the genre in other significant ways. The Ti-Girls are able to track down Penny's children after they record her maternal instinct and then bathe themselves in it with the Weeper's Ray of Truth. Feminine empowerment is not separate from motherhood, nor is it separate from a narrative of an American social utopia; it is, in fact, the basis for it. 


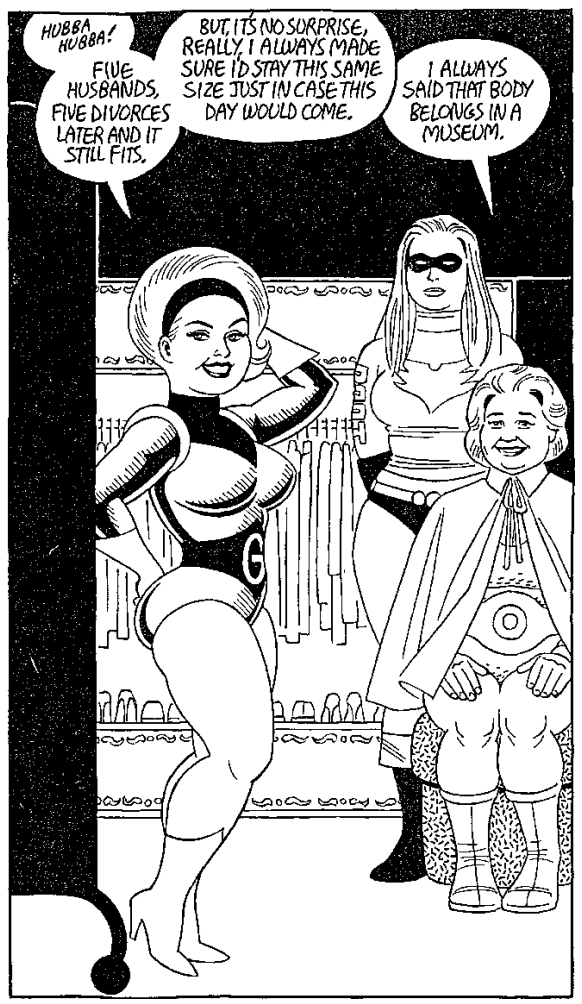

Divorced, middle-aged Latinas set a new standard for superheroic identity.

16 Representations of diverse superheroic bodies are central to Hernandez's rewriting of this narrative; the female, non-white, and middle-aged bodies that populate God and Science exceed the boundaries of representation in mainstream comic books [Image 1]. As Bukatman points out, in mainstream superhero comic books "the acquisition of costume, mask and logo might constitute a... rebirth into the symbolic," transferring "issues of birth and identity from the field of maternal power to the realm of the patriarchy" (55). Patriarchy's symbolic power of reproduction is evident in the fact that the Zolars are named after Dr. Zolar (literally a reinscription of him) and socially inscribed patriarchal power is manifested in the group's rule that each member automatically is removed from the group at age twenty-one; that is, when they reach adulthood. Such a rule potentially circumvents the resistance Dr. Zolar faced from the adult Ti-Girls who actively rejected his control. This resistance is articulated according to the wearing of masks. While most of the Ti-Girls do not wear a mask because, as Espectra offers, "Why hide all this beauty?," the African American Weeper does. Espectra informs Angel that the Weeper's mask " is her persona... It goes back to when her great great grandmother wore it to battle the Ku Klux Klan after the Civil War" (Hernandez 80). Masks are thus not simply a genre signifier but a volatile social marker. Espectra relates that in the 1960s she and Golden Girl "burned our masks on the day we axed Dr. Zolar as our leader. It felt so liberating and oh, so scary at the same time. Then all the other teams stood against us" (ibid). The patriarchal repression of Dr. Zolar, the male scientist who was the original leader of the team, is acknowledged and resisted via the mask as an expression of female autonomy (and which, as an echo of bra-burning of the 1960s, aligns these female superheroes with the women's liberation movement). This gesture subsequently marks the Ti-Girls as queer in the eyes of other superheroes. 
This revelation of an authentic self, of the empowered, liberated female superhero, is reflected in Angel's transformation into Boot Angel over the course of the story. Her transformation is reinforced by her mother's confession that she was once the superhero Aztlana. This revelation is particularly significant given that Aztlan is the mythical place of origin for Chicanos and an important symbol of the Chicano movement of the 1960s and 1970s. In this way, Hernandez links the superheroes of his childhood with contemporaneous political movements. Further, Hernandez has commented that "Hoppers is an imaginary barrio based on all the real life barrios in Southern California, or in all Aztlan for that matter" ("Letters to L \& R"). Place is inherently political and thus the barrio is a microcosm of the nation. Significantly, Boot Angel dons her mother's Aztlan t-shirt from this point onward, confirming the conflation of past and present, creator and character, the local and the national in an expression of utopian affect and agency [Images 2 and 3].

Images 2 \& 3
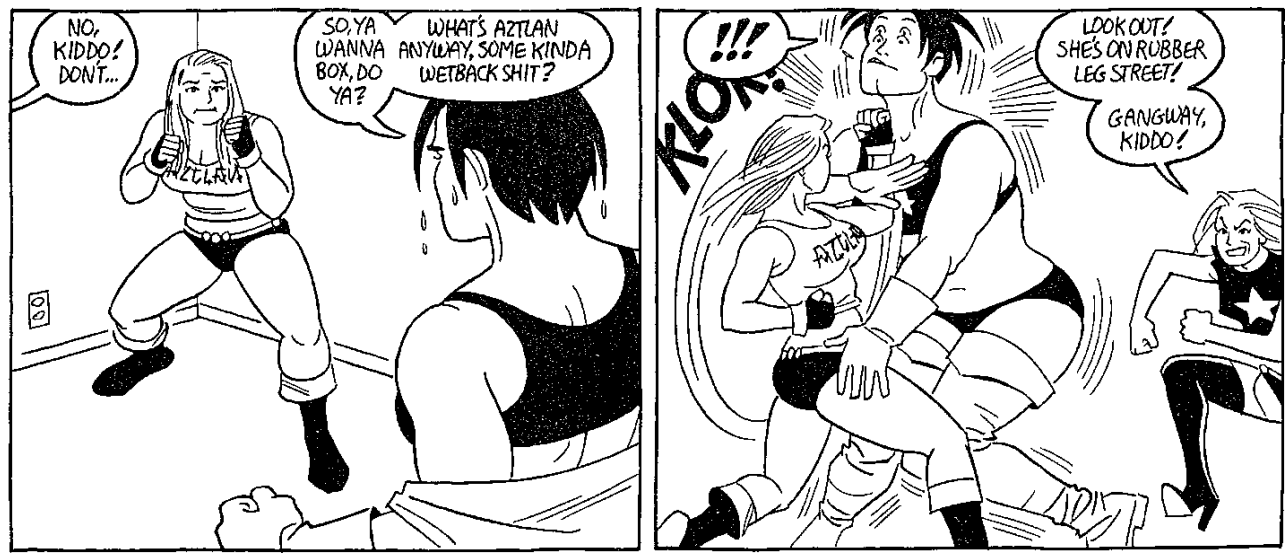

Cultural identity as the source of superheroic power

17 Such affect is a trope of queer identity, what Sara Ahmed terms "queer feelings." According to Ahmed, "emotions work as a form of capital: affect does not reside positively in the sign or commodity, but is produced as an effect of its circulation ... the more signs circulate, the more affective they become" (45). Accordingly, the superhero as a commodity and as conduit for fan affect is an integral link in a circuit of meaning between the private and the public; that is, the articulation of the consumer as a social being. Importantly, then, as Ahmed states, "'the subject' is simply one nodal point in the economy, rather than its origin and destination" (46). This relationship between the superhero genre and its fans, and between the genre's producers and consumers, confirms its essentially open, generative capacity. That is to say, the superhero, fan, and producer subjectivities are always transforming. In the affective relationship with the object, the subject becomes an affect-generating object herself. Thus Maggie's fantasizing, informed and articulated by her comic book collection, inspires Angel to don her own superhero costume and actualize her affective desire for agency as an overweight Chicana superhero.Comparably, Hernandez's own foregrounded subjectivity as fan-turned-creator and as a Chicano independent writer-artist, serves as a nodal point in the circuit of meaning between mass culture and the consumer. Through Angel, Hernandez expresses his own relationship to the naturalized ideology of the superhero genre, uncovering its latent potential for utopianism defined by 
difference, not sameness. Ahmed reminds us that "bodies take the shape of norms that are repeated over time and with force. The work of repetition involves the concealment of labour under the sign of nature" (145). The superhero is vexed in this regard because he/she is both normative and non-normative (or queer), both of this world (mundane) and separate from it (fantastic). Thus the repetition and recirculation of the superhero pronounces its vexed qualities.For Ahmed, queer feelings are those that heteronormativity refuses to recognize as legitimate. Consequently, discomfort about not fitting into heteronormative standards is generative; it produces different ways to inhabit norms; thus discomfort is "not about assimilation or resistance" (Ahmed 155). Accordingly, Hernandez seeks to reconfigure the operating principles of the medium, to, in his words, "change the rules for the better. It can be fun and honest at the same time" (Hignite 89). In doing so, Hernandez confirms Ahmed's contention that "pleasure is expansive... Pleasures open bodies to worlds through an opening up of the body to others" (164). As a pop culture loving Chicano, Hernandez transforms his own liminality into an expression of the utopian potential of American society via an otherwise segmented mass culture. If, as Ahmed says, "the hope of the queer is... [to create] the possibility of" new social forms, Hernandez, like Angel, expresses this hope by harnessing the utopian underpinnings of the superhero as an expressly American icon (165). Thus he reveals the inherent queerness that resides underneath the stolid façade of the apparently heteronormative superhero. Hernandez reminds us that, for all of his/her ideological conservativism, the superhero is primarily a figure of excess and difference.

\section{Fortresses of Solidarity}

18Hernandez displays his affect openly on the page and it is here that we can locate how he reconfigures the iterative and derivative qualities of mainstream superhero comic books in order to expose the cultural labor that goes into maintaining superhero comic books as meaning-making vehicles. For example his visual quotations of such iconic Silver Age artists as Jack Kirby and Steve Ditko are more than simply homages. They serve as evidence of the ways in which comic book fans romanticize particular artists to validate their own interest in Silver Age comic books (the label "Silver Age" itself casting a heavily romanticized patina onto the past). More than just evoking Silver Age comics, Hernandez necessarily evokes the consumption of them. The drugstore or supermarket spinner rack of the past is evoked by the structure of God and Science. Each chapter of the graphic novel is separated as if one in a series of Ti-Girls Adventures comics by consecutively numbered covers (which also show visible signs of age). The cover breaks convey the periodized structure of a bi-monthly comic book, a utopian gesture contained within the limits of the graphic novel. Through the affect of nostalgia, then, Hernandez evokes memories of spaces and moments of consumption as texts. 


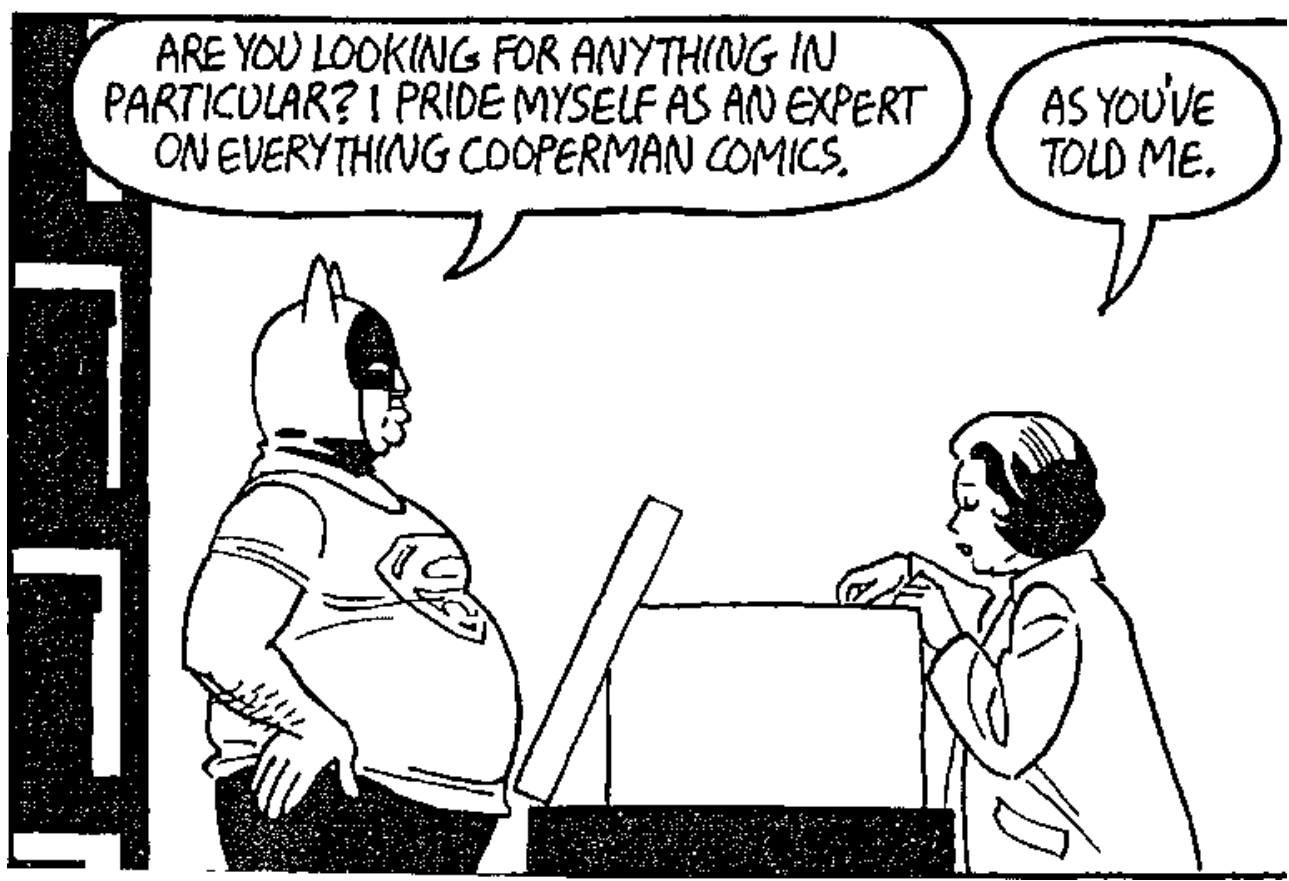

The utopian potential of the superhero is disciplined by mass culture

19 As a contemporary graphic novel sold in specialty comic book shops, God and Science marks that space of consumption as the generative site of queer feelings, that is, of utopian affect. Not only does Santa provide Maggie with old comic books that unlock the mystery of the superhero universe, but so too do dealers at a comic book show and shop. This latter is particularly significant, given that the clerk wears a Batman cowl and Superman t-shirt [Image 4]. The comic book shop is depicted as a space for utopian self-reimagining, defined by one's mastery of pop culture. By the very early 1980s, traditional venues for selling comic books (supermarkets and drugstores) increasingly gave way to the direct-market comic book shop that catered to a predominantly adult market. These shops fostered the emergence of an alternative comic book market and it is in this period that Love and Rockets was born. As Charles Hatfield observes, this period saw "the growth of a hermetic yet economically advantageous market, one that catered to mainstream comic book fans but sustained, at its margins, the fevered sense of artistic possibility ignited by [underground] comix" (ix).v As the audience and the distribution circuit for comics contracted, the specialty comic book shop became a selfcontained space for comic book consumers that could sustain a variety of seemingly contradictory impulses. In this way, the specialty comic book store, thoroughly devoted to the sale of new and old comics (and related ancillary products) to a small market, is a utopian space defined by affect. For the first time, the specialty comic book shop offered readers a discrete space solely dedicated to the medium they loved. According to Fredric Jameson, "Utopian space is an imaginary enclave within real social space... the very possibility of Utopian space is itself a result of spatial and social differentiation" (15). The specialty comic book shop's confirmation of the social marginalization of adult comic book readers serves as its essential appeal to customers. It offers a safe place in which the fan can most openly express their fandom. 
20 Because the utopian in this space is always personal, always individualized in the consumption of mass produced objects, it is a space that necessarily harbors, even encourages, contradictions. Thus one finds a mixture of old and new comics, mainstream and alternative titles, and various genres in the same space. The earliest issues of Love and Rockets were ideally suited to this environment, with their mixture of dinosaurs and science fiction tropes and quotidian observations about daily life and interpersonal relationships in the barrio. A one-page story in the first issue (published in 1982) exemplifies these contradictions: in "Penny Century, You're Fired!" we find Penny daydreaming at her factory job about becoming a superhero. This seemingly incidental story in fact reveals the utopian desires of both Penny and Hernandez, each realized nearly 30 years later in God and Science. Penny's utopian desire has also distinguished her from Hernandez's other characters, in that over the thirty years that he has been producing Love and Rockets stories, all of his characters have visibly aged except for Penny. As Maggie says in God and Science: "I've known Penny for quite a few years and in all that time, she never aged. Like, she was not regular flesh and blood, but like, this drawing that was clipped from a comic book and pasted down here on Earth" (Hernandez 128).

21 Hernandez's radical rejection of the non-aging characters that typify most comic book characters (from Archie to Superman) marks the non-aging of the superherowannabe as itself a radical notion. According to Corey Creekmur, "By directly injecting chronology and temporality into his narrative... [Hernandez] brings the impact of the past on the present... into play." This maneuver is further realized in the reflexivity of God and Science, its references to Silver Age comics locating it (and Hernandez and his readers) within a historical narrative of superhero comic books. Elizabeth Freeman (following Dana Luciano) notes that "nations and other public forms of engroupment depend not only on progressive, linear time and the cyclical time that buttresses it but also on the illusion that time can be suspended" (6). In his diegetic and extra-diegetic intersecting of linear time and the suspension of time, Hernandez not only deconstructs the superhero genre but the nation as well. His work follows what Freeman sees as "the ways that nonsequential forms of time... can also fold subjects into structures of belonging and duration that may be invisible to the historicist eye" (xi). God and Science confirms Freeman's contention that what she calls queer temporality "generates a discontinuous history of its own" (xi). Thus, the ambiguity of the spatial and temporal relationship between God and Science and his Locas stories speaks to the inherent ambiguities of Silver Age superhero comic books and American identity. In an email to this author Hernandez characterizes the relationship of the superheroes of God and Science to his Locas characters as "sort of like having a distant cousin you never met. They're out there somewhere on this planet." Comparably, the nation as an imagined community (per Benedict Anderson), like comic book fandom, requires an acknowledgement of those members who are "distant cousins": the Other who is required, paradoxically, for the constitution of Self and of that Self's place within a polysemic collective.

22 In 1999 and 2000 Hernandez produced a series of stories about a family of superheroes called Los Super Sonicos ("California's \#1 Super Family") for the children's comic book series Measles. These stories were inspired by an amateur comic book written and drawn by one of Hernandez's older brothers when they were children in 1968, indicating the utopian capacity of alternative comic books to allow the creator 
full expression of personal desires that originate in childhood. His remediation of a homemade comic book by one of his brothers (who did not become a comics professional) actualizes the utopian promise of that comic - to one day become a comics pro, embedding one's Chicano identity into the text. By implication, California's \#1 Super Family is an appellation applicable to Gilbert and Jaime Hernandez themselves; "Los Bros," the name they are typically known by, could just as well be the name of a super team or a group of wrestlers. This is the utopian promise realized in all of Hernandez's work and which is most directly implicated in childhood fantasies of transcendence in God and science. The transcendence of the everyday that is represented by superheroes is actualized by his self-transformation into a comic book creator. The daydreams of Hernandez the young comic book reader are remediated as the daydreams of Penny, Maggie, and Angel. One utopian yearning is satisfied in the expression of another and in the process both the superhero genre and America offer structures to be acknowledged as well as surpassed. In doing so Hernandez confirms the utopian potential of each, limited only by the capacity of the individual to see him or herself in the liminal space between the individual and the collective, between the past and the present, between Chicano and Anglo. Like the superheroes in God and Science, this utopian self is visible when we choose to acknowledge not simply its existence, but its power to positively transform the very boundaries of individual and national identities.

\section{BIBLIOGRAPHY}

Ahmed, Sara. The Cultural Politics of Emotion. New York: Routledge. 2004. Print.

Aldama,Frederick Luis. "Interview with Jaime Hernandez." Spilling the Beans in Chicanolandia: Conversations with Writers and Artists. Austin: University of Texas Press, 2006, 119-128. Print.

Bukatman, Scott. Matters of Gravity: Special Effects and Superman in the $20^{\text {th }}$ Century. Durham, NC and London: Duke University Press. 2003. Print.

Creekmur, Corey. “Remembering Locas.” The Hooded Utilitarian. 29 Mar 2012. 5 may 2013.

http://hoodedutilitarian.com/2012/03/remembering-locas/

Dávila, Arlene. Latinos, Inc.: The Marketing and Making of a People. Berkeley: University of California Press. 2001. Print.

De Lauretis, Teresa. "Queer Theory: Lesbian and Gay Sexualities: An Introduction." differences 3.2 (1991). Print.

Doty, Alexander. Making Things Perfectly Queer: Interpreting Mass Culture. Minneapolis and London: University of Minnesota Press. 1993. Print.

Freeman, Elizabeth. Time Binds: Queer Temporalities, Queer Histories. Durham: Duke University Press, 2010. Print. 
Garber, Marjorie. Vested Interests: Cross-Dressing and Cultural Anxiety. New York: Routledge. 1992. Print.

Hatfield, Charles. Alternative Comics: An Emerging Literature. Jackson: University Press of Mississippi, 2005. Print.

Hernandez, Jaime. God and Science: Return of the Ti-Girls. Seattle: Fantagraphics Books, 2012. Print.

Hignite, Todd. The Art of Jaime Hernandez: The Secrets of Life and Death. New York: Abrams, 2010.

Print.

Jameson, Fredric, Archaeologies of the Future: The Desire Called Utopia and Other Science Fictions. New York: Verso, 2007. Print.

"Letters to L \& R." Love and Rockets: New Stories. No. 6. Seattle: Fantagraphics Books, 2013. Print.

Martínez, Ernesto Javier. "Shifting the Site of Queer Enunciation: Manuel Muñoz and the Politics of Form." Gay Latino Studies: A Critical Reader. Ed. Michael Hames-García and Ernesto Javier Martínez. Durham, NC: Duke University Press, 2011. 226-249. Print.

Medhurst, Andy. "Batman, Deviance and Camp." The Many Lives of the Batman: Critical Approaches to a Superhero and His Media. Ed. Roberta E. Pearson and William Uricchio. New York and London: Routledge. 1991. 149-163. Print.

Saldívar, José David. “Chicano Border Narratives as Cultural Critique.” Criticisms in the Borderlands. Ed. Hector Calderón and José David Saldívar. Durham, NC: Duke University Press, 1991. 167-180. Print.

\section{NOTES}

i. God and Science was first published as "Ti-Girls Adventures Number 34" in the first two issues of Love and Rockets: New Stories in 2008 and 2009. While regular readers of Love and Rockets would be aware of her sexuality, it is not mentioned in this story.

ii. Like Maggie, Penny appeared in the first issue of Love and Rockets in 1982 and has been a regular character in Hernandez's stories ever since.

iii. Needless to say, Jimmy Olsen's radical physical transformations are regarded as excessively anti-normative in contrast to the literal and symbolic stability of Superman, the proverbial "Man of Steel."

iv. The story in question is "The Death of Superman!" in Superman no. 149 (November 1961). Significantly, this tale is one of the many "Imaginary Stories" that appeared in Silver Age DC comic books, narratives that exist outside of established continuity. In this way, Hernandez is clearly playing with the border between continuity and the "Imaginary Stories" established by DC in the blurring of his Locas continuity and the world of the Ti-Girls.

v. Recalling his exposure to underground comix as an adolescent, Hernandez notes, "What I really liked about the underground comic was the freedom-that the authors were doing exactly what they wanted without any editorial pressure or a big company to tell them yes or no. They represented the underdog: that was interesting to someone growing up Chicano" (Aldama 123). 


\section{ABSTRACTS}

This paper examines the ways in which artist-writer Jaime Hernandez engages with issues of national belonging in terms of ethnicity and gender in his 2012 superhero graphic novel God and Science: Return of the Ti-Girls. By presenting the adventures of a group of multi-racial female superheroes, Hernandez productively exploits the inherent social marginality of the superhero, conflating it with a comparable marginality of non-whites and women in American society. By doing so, he rearticulates that marginality as an actualization of the promise of pluralistic utopianism inherent in American society. As a Chicano and fan of Silver Age superhero comic books himself, Henandez also realizes this ethos for himself in the very creation of this work.

\section{INDEX}

Mots-clés: Jaime Hernandez

Keywords: America, queer, Superhero, utopia

\section{AUTHOR}

\section{MATT YOCKEY}

University of Toledo 